\title{
MENINGKATKAN PENGGUNAAN MEDIA SOSIAL DENGAN BIJAK MELALUI LAYANAN KONSELING INDIVIDU DENGAN STRATEGI PENDEKATAN KOGNITIF PERILAKU DI SMKN 1 SINGOSARI KABUPATEN MALANG
}

\author{
Novita Karnida Khurri \\ SMKN 1 Singosari \\ khurrifaza@gmail.com
}

\author{
Edi Purwanto
}

SMP Negeri 1 Widang-Tuban

edirakabuming86@gmail.com

\begin{abstract}
Abstrak
Penelitian ini dilakukan berdasarkan permasalahan yaitu bagaimana meningkatkan penggunaan media sosial dengan bijak melalui layanan konseling individu dengan strategi pendekatan koginitif perilaku di SMKN 1 Singosari. Penelitian ini bertujuan untuk mengetahui sejauh mana meningkatnya penggunaan media sosial dengan bijak melalui layanan konseling individu dengan strategi pendekatan kognitif perilaku di SMKN 1 Singosari kabupaten Malang. Penelitian ini menggunakan penelitian tindakan (action research) sebanyak dua putaran. Setiap putaran terdiri dari empat tahap yaitu : rancangan, kegiatan dan pengamatan, refleksi dan revisi. Sasaran penelitian ini adalah siswa Kelas X AB SMKN 1 Singosari Kabupaten Malang semester gasal tahun pelajaran 2018/2019. Data yang diperoleh berupa hasil angket dan lembar observasi kegiatan layanan konseling. Hasil skor pada angket siklus I lebih rendah dan mengalami peningkatan pada siklus II yaitu dari 58\% menjadi 89\%. Hasil dari pengisian evaluasi proses dari skor 55 dengan persentase 55\% menjadi skor 90 dengan persentase $90 \%$ dan evaluasi hasil dari skor 13 dengan persentase 54\% menjadi skor 27 dengan persentase $96 \%$. Simpulan dari penelitian ini adalah meningkatkan penggunaan media sosial dengan bijak dapat dilakukan melalui konseling individu dengan strategi pendekatan kognitif perilaku.
\end{abstract}

Kata Kunci: Bijak bermedia sosial, konseling individu,pendekatan kognitif perilaku

\begin{abstract}
This research was conducted based on the problem, namely how to increase the use of social media wisely through individual counseling services with a behavioral cognitive approach strategy at SMKN 1 Singosari. This study aims to determine the extent to which the increasing use of social media wisely through individual counseling services with a cognitive-behavioral approach strategy at SMKN 1 Singosari, Malang district. This study used two rounds of action research. Each round consists of four stages, namely: design, activity and observation, reflection and revision. The target of this research is students of Class X AB SMKN 1 Singosari Malang Regency odd semester of 2018/2019 academic year. The data obtained were in the form of questionnaires and observation sheets of counseling service activities. The score results in the questionnaire cycle I were lower and increased in cycle II, from 58\% to $89 \%$. The results of filling out the evaluation process from a score of 55 with a percentage of $55 \%$ to a score of 90 with a percentage of $90 \%$ and the evaluation of the results from a score of 13 with a percentage of $54 \%$ to a score of 27 with a percentage of $96 \%$. The conclusion of this study is that increasing the use of social media wisely can be done through individual counseling with a cognitivebehavioral approach strategy.
\end{abstract}


Jurnal HELPER, Vol 36 No 2 (2019) 08 - 16

Bimbingan dan Konseling Universitas PGRI Adi Buana Surabaya

ISSN: 02162938

Keywords: social media wise, individual counseling, cognitive-behavioral approach

\section{LATAR BELAKANG}

Teknologi komunikasi yang di iringi dengan kehadiran media sosial telah memberi banyak perubahan dalam kehidupan bermasyarakat terutama bagi generasi milenial. Kondisi saat ini banyak generasi milenial yang menggunakan media sosial hanya berorientasi pada kesenangan dan kepuasan pribadi saja dan mengikuti hal yang lagi viral. Penayangan data pribadi tanpa disaring, foto-foto yang kurang sesuai dengan norma agama dan adat istiadat, senang menguplaod semua kegiatan di beberapa media sosial dan lain sebagainya yang berakibat pada bertambahnya tingkat penyimpangan perilaku di masyarakat terutama kalangan generasi milenial ini. Sehingga mereka memerlukan kemampuan untuk menggunakan media sosial dengan bijak.

Kondisi saat ini tidak sedikit orang yang mengalami stress hingga depresi akibat dari penggunaan media sosial, orang yang tadinya membuka media sosial untuk menjadi pintu terbukanya mengaktualisasikan diri malah menjadi ladang untuk hal negatif, mulai dari menyombongkan diri sendiri,menghujat,mencaci maki dan menyebarkan berita yang kurang benar, tampil sesempurna mungkin dengan tidak menjadi diri sendiri dan lain sebagainya. Kenyataannya seringkali postingan orang bukan hanya sekedar update status dan uploud foto selfie tapi mereka juga cenderung memposting hal yang tidak pantas seperti dengan cara meluapkan masalah pribadi pada halayak umum dengan tayangan atau kata-kata yang kurang sesuai dengan norma dan adat istiadat serta agama.

Hal ini juga terjadi pada salah satu peserta didik/konseli kelas X AB1 SMKN 1 Singosari yang mulai kurang bijak dalam menggunakan media sosial ini. Terbukti dari hasil observasi pada tanggal 27 September 2018 yang menunjukkan bahwa peserta didik/konseli masih kurang bijak dalam menggunakan media sosial. 202Penayangan data pribadi tanpa disaring, foto-foto yang kurang sopan, biasa berjilbab sekarang foto yang di upload tidak berjilbab dan senang menguplaod semua kegiatan di beberapa media sosial, dan akhir-akhir ini melakukan chat di group WA sering pakai kata-kata kotor, setiap hari dan setiap saat terus menggunakan medsos hingga tugas rumah dan tugas sekolah tidak diselesaikan dengan baik dan tidak sesuai waktu yang ditentukan, hubungan dengan teman-teman juga mulai renggang dibuktikan dengan menghindari komunikasi antar teman. Aktivitas hari-hari hanya berorientasi dunia maya saja, konseli juga menjadi lebih cepat tersinggung apabila diberi masukan.

Fenomena di atas sangat menarik apabila diteliti. Agar dapat membantu peserta didik/konseli dalam menganalisis, mengklasifikasi dan menentukan hal apa saja yang dapat meningkatkan penggunaan media 
Jurnal HELPER, Vol 36 No 2 (2019) 08 - 16

Bimbingan dan Konseling Universitas PGRI Adi Buana Surabaya

ISSN: 02162938

sosial dengan bijak. Bimbingan dan konseling mempunyai peranan yang sangat besar yakni dengan menerapkan salah satu layanan bimbingannya yang digunakan untuk membantu peserta didik/konseli agar dapat meningkatkan penggunaan media sosial dengan bijak. Salah satu layanan bimbingan tersebut adalah layanan responsif yakni layanan konseling individu. Layanan konseling merupakan suatu proses yang terjadi dalam hubungan seseorang dengan seseorang yaitu individu yang mengalami masalah yang tidak dapat diatasinya, dengan seorang petugas profesional yang telah memperoleh latihan dan pengalaman untuk membantu agar klien memecahkan kesulitanya. Menurut brammer (1979) proses konseling adalah peristiwa yang telah berlangsung dan memberi makna bagi peserta koseling tersebut (konselor dan klien).

Pelaksanaan konseling individu memerlukan strategi pendekatan yang tepat dalam menyelesaikan suatu masalah, seperti halnya dalam penelitian ini akan menentukan strategi sesuai dengan masalah yang akan diteliti yaitu strategi pendekatan kognitif perilaku. Strategi pendekatan ini adalah pendekatan konseling yang menitik beratkan pada restrukturisasi atau pembenahan kognitif yang menyimpang akibat kejadian yang merugikan dirinya baik secara fisik maupun psikis. Konseling ini akan diarahkan kepada modifikasi fungsi berpikir, merasa dan bertindak, dengan menekankan otak sebagai penganalisa, pengambil keputusan, bertanya, bertindak, dan memutuskan kembali. Tujuan dari pendekatan kognitif perilaku yaitu mengajak individu untuk belajar mengubah perilaku, menenangkan pikiran dan tubuh sehingga merasa lebih baik, berpikir lebih jelas dan membantu membuat keputusan yang tepat. Hingga pada akhirnya melalui konseling individu dengan strategi pendekatan kognitif perilaku diharapkan dapat membantu konseli dalam menyelaraskan berpikir, merasa dan bertindak. Mengacu dengan latar belakang di atas, maka penulis mengambil judul "Meningkatkan Penggunaan Media Sosial dengan Bijak Melalui Layanan Konseling Iindividu dengan Strategi Pendekatan Kognitif Perilaku di SMKN 1 Singosari,”

\section{KAJIAN TEORI}

1. Layanan Konseling Individual

$$
\text { Menurut Walgito }
$$
konseling merupakan bantuan yang diberikan kepada individu untuk memecahkan masalah kehidupannya dengan cara wawancara dan dengan cara yang sesuai dengan keadaaan yang dihadapi individu untuk mencapai kesejahteraan hidupnya. Peserta didik/konseli yang dibimbing, merupakan individu yang sedang dalam proses perkembangan sesuai dengan usianya. Sedangkan brammer (1979) menyampaikan proses konseling adalah peristiwa yang telah berlangsung dan 
Jurnal HELPER, Vol 36 No 2 (2019) 08 - 16

Bimbingan dan Konseling Universitas PGRI Adi Buana Surabaya

ISSN: 02162938

memberi makna bagi peserta koseling tersebut (konselor dan klien).

Tujuan konseling adalah memberikan bantuan kepada peserta didik/konseli yang sedang mengalami masalah untuk segera dapat menyelsesaikan masalah yang sedang dihadapi. Penyelesaian ini akan sangat membantu peserta didik/konseli dalam membentuk kepribadian seutuhnya sehingga seua tugas perkembangan dapat diselesaikan dengan sempurna. Ketidaksempurnaan ini akan sangat memperngaruhi kehidupan selanjutnya, tentunya berpengaruh pada semua segi dalam kehidupannya baik pribadi,sosial,belajar maupun karir. Konselor menetapkan tujuan untuk membantu kliennya memiliki kemampuan menolong diri sendiri, sehingga dapat menghadapi situasi hidup selanjutnya dengan lebih konstruktif. (Oates, 1974:9). Asas-asas layanan konseling individu yang akan mendukung kelancaran prosesnya, antara lain: asas kerahasiaan,asas kesukarelaan,asas kenormatifan dan keahlian.

\section{Pendekatan Kognitif Perilaku}

Layanan konseling individu yang dilakukan akan menggunakan strategi pendekatan kognitif perilaku untuk membantu peserta didik/konseli dalam meningkatkan penggunaan media sosial dengan bijak. Menurut Aaron T. Beck (1964) mendefinisikan CBT sebagai pendekatan konseling yang dirancang untuk menyelesaikan permasalahan konseli pada saat ini dengan cara melakukan restrukturisasi kognitif dan perilaku yang menyimpang. Pendekatan ini didasarkan pada beberapa hal yakni formulasi kognitif, keyakinan pada pemikirannya dan strategi perilaku yang mengganggu peserta didik/konseli. Tujuan dari pendekatan ini yaitu mengajak individu untuk mau belajar mengubah perilaku yang telah dilakukan, menmbuat konsep pikiran dengan benar, menenangkan diri dan tubuh sehingga merasa lebih rileks, berpikir lebih luas dan terbuka serta dapat membantu membuat keputusan yang tepat sesuai dengan kondisi saat ini. Hingga pada akhirnya dengan pendekatan kognitif perilaku diharapkan dapat membantu konseli dalam menyelaraskan berpikir, merasa dan bertindak dalam meningkatkan penggunaan media sosial dengan bijak.

\section{Media Sosial}

Menurut Caleb T. Carr dan Rebecca A. Hayes (2015) Media sosial adalah media berbasis Internet yang memungkinkan pengguna berkesempatan untuk berinteraksi dan mempresentasikan diri, baik secara 
Jurnal HELPER, Vol 36 No 2 (2019) 08 - 16

Bimbingan dan Konseling Universitas PGRI Adi Buana Surabaya

ISSN: 02162938

seketika ataupun tertunda, dengan khalayak luas maupun tidak yang mendorong nilai dari user-generated content dan persepsi interaksi dengan orang lain. Pengguna jejaring sosial dituntut untuk cerdas dan bijak dalam menangkap sebuah informasi, bila ingin ikut menyebarkan informasi tersebut, ada baiknya kita melakukan kroscek akan kebenaran informasi terlebih dahulu.

\section{METODOLOGI PENELITIAN}

Metode penelitian adalah cara yang digunakan oleh peneliti dalam mengumpulkan data penelitiannya (Suharsimi Arikunto: 2002). Metode yang digunakan dalam penelitian ini adalah penelitian tindakan kelas. Penelitian tindakan kelas dalam bahasa Inggris disebut dengan istilah classroom action research. Dari nama tersebut terkandung tiga kata yakni (Suharsimi Arikunto: 2007).

1. Penelitian, menunjukkan pada suatu kegiatan mencermati suatu objek dengan cara menggunakan cara dan aturan metodologi tertentu untuk memperoleh data atau informasi yang bermanfaat dalam meningkatkan mutu suatu hal yang menarik minat dan penting bagi peneliti.

2. Tindakan, menujukkan pada suatu objek kegiatan yang sengaja dilakukan dengan tujuan tertentu. Penelitian berbentuk rangkaian siklus kegiatan untuk siswa.

3. Kelas, dalam hal ini tidak terikat pada pengertian ruang kelas, tetapi dalam pengertian yang lebih spsifik, yakni sekelompok siswa yang dalam waktu yang sama, menerima pelajaran yang sama dari guru yang sama pula.

Sehingga dengan menggabungkan ketiga kata tersebut menjadi, Penelitian Tindakan Kelas. Dapat disimpulkan bahwa Penelitian Tindakan Kelas merupakan suatu pencermatan terhadap kegiatan belajar berupa sebuah tindakan, yang sengaja dimunculkan dan terjadi dalam sebuah kelas secara bersama. Pada bab ini dibahas tentang metodologi penelitian dan langkah-langkah penelitian secara aplikatif, yang meliputi: (1) rancangan dan jenis penelitian, (2) data dan sumber data, (3) pengumpulan data, (4) analisis data, (5) instrument penelitian, dan (6) prosedur penelitian. Penelitian ini dilaksanakan sesuai dengan rancangan penelitian model Hopkins yang diawali dengan tindakan pendahuluan kemudian dilanjutkan perencanaan, tindakan, pengamatan, dan refleksi. Penelitian dilakukan sebanyak 2 siklus. Hasil evaluasi pada siklus I masih belum tuntas, sehingga dilakukan perbaikan pada siklus II. Refleksi siklus I dilakukan untuk menentukan langkahlangkah perbaikan pada siklus II. 
Jurnal HELPER, Vol 36 No 2 (2019) 08 - 16

Bimbingan dan Konseling Universitas PGRI Adi Buana Surabaya

ISSN: 02162938

Setting penelitian ini meliputi tempat Penelitian yang akan dilaksanakan melalui daring. Proses tersebut dipilih karena kondisi pandemi saat ini.Waktu penelitian perbaikan pelayanan ini dilakukan pada semester ganjil tahun ajaran 2018/2019. Penelitian dilaksanakan dalam dua siklus yaitu siklus I pada tanggal 16 Oktober 2018 dan siklus II pada tanggal 23 Oktober 2018. Melalui kedua siklus tersebut dapat diamati pada kegiatan layanan konseling individu dengan menggunakan pendekatan kognitif perilaku untuk meningkatkan penggunaan media sosial dengan bijak. Subjek penelitian adalah peserta didik/konseli yang kelas $\mathrm{X}$ AB1 SMKN 1 Singosari. Layanan konseling individu yang menjadi sasaran penelitian adalah peserta didik/konseli kelas X AB1

Teknik pengumpulan data yang digunakan dalam penelitian ini adalah sebagai berikut. Observasi,tes,wawancara dan kondisi dilapangan. Data-data yang dianalasis adalah hasil observasi aktivitas guru BK/Konselor dan peserta didik/konseli, hasil wawancara, hasil catatan lapangan, dan hasil evaluasi peserta didik/konseli. Data berupa hasil observasi aktivitas guru BK/Konselor, dan hasil catatan lapangan dianalisis berupa deskripsi dalam bentuk penarikan simpulan. Data hasil evaluasi peserta didik/konseli dan hasil observasi aktivitas peserta didik/konseli dianalisis dengan angka-angka. Dalam PTK ini yang akan dilihat adalah indikator kinerjanya.

Maka diperlukan indikator sebagai berikut:

1. Skor dan interpertasi masuk dalam kategori tinggi.

2. Hasil angket termasuk dalam kategori sangat baik dari siklus I dan siklus II.

3. Keaktifan guru BK/Konselor dan peserta didik/Konseli dalam ketegori baik berdasarkan hasil pengamatan guru BK/Konselor, peneliti dan pengamat.

4. Setelah pelaksanaan penelitian tindakan kelas ini diharapkan peserta didik/konseli dapat meningkatkan penggunaan media sosial dengan bijak dengan kriteria : hasil skor pada angket meningkat.

\section{HASIL DAN PEMBAHASAN}

a. Hasil penelitian

Hasil pada siklus I yaitu pelaksanaan layanan konseling individu dalam meningkatkan penggunaan media sosial dengan bijak menunjukkan persentase $55 \%$ dan 54\%. Hasil tersebut menunjukkan bahwa pada siklus pertama belum mencapai ketuntasan dengan maksimal dalam meningkatkan penggunaan media sosial. Hal ini disebabkan karena peserta didik/konseli masih ragu dalam melaksanakan komitmen yang sudah ditentukan. Pelaksanaan kegiatan layanan konseling individu dengan strategi pendekatan kognitif perilaku pada siklus I ini masih 
Jurnal HELPER, Vol 36 No 2 (2019) 08 - 16

Bimbingan dan Konseling Universitas PGRI Adi Buana Surabaya

ISSN: 02162938

terdapat kekurangan, sehingga perlu adanya revisi untuk dilakukan pada siklus berikutnya.

1. Guru BK/Konselor perlu lebih terampil dalam melaksanakan konseling individu dengan strategi pendekatan kognitif perilaku.

2. Guru BK/Konselor perlu menambahkan penguatan konsep pemikiran dan kontrol perilaku secara tepat sehingga peserta didik/konseli dapat melaksanakan semua solusi dengan keyakinan penuh dan dilaksanakan dengan maksimal.

3. Guru BK/Konselor harus lebih terampil dan bersemangat dalam memotivasi peserta didik/konseli supaya lebih antusias.

Sedangkan hasil siklus II yaitu pelaksanaan layanan konseling individu dalam meningkatkan penggunaan media sosial dengan bijak diperoleh skor evaluasi hasil skor 27 dan persentase 96\%. Hasil tersebut menunjukkan bahwa pada siklus II sudah mencapai ketuntasan dengan maksimal dalam meningkatkan penggunaan media sosial dengan strategi pendekatan kognitif perilaku. Hal ini disebabkan karena peserta didik/konseli sudah mempunyai keyakinan penuh dalam melaksanakan komitmen yang sudah ditentukan.

Pelaksanaan kegiatan layanan konseling individu dengan strategi pendekatan kognitif perilaku pada siklus II ini sudah terlaksana dengan baik, sehingga tidak diperlukan siklus berikutnya.

1. Guru BK/Konselor lebih terampil dalam melaksanakan konseling individu dengan strategi pendekatan kognitif perilaku.

2. Guru BK/Konselor menambahkan penguatan konsep pemikiran dan kontrol perilaku secara tepat sehingga peserta didik/konseli dapat melaksanakan semua solusi dengan keyakinan penuh dan dilaksanakan dengan maksimal.

3. Guru BK/Konselor lebih terampil dan bersemangat dalam memotivasi peserta didik/konseli sangat aktif,kooperatif dan antusias selama konseling individu berlangsung

b. Pembahasan

Penelitian ini menunjukkan bahwa konseling individu dengan strategi pendekatan kognitif perilaku berdampak positif dalam meningkatkan penggunaan media sosial yang bijak. Hal ini dapat dilihat dari hasil siklus I dan siklus II yang menunjukkan peningkatan persentase yang signifikan pada evaluasi hasil yaitu dari 54\% naik menjadi 96\%. Ditambahkan pada hasil evaluasi proses yang menunjukkan persentase 55\% menjadi $90 \%$.

Aktivitas

peserta

didik/konseli mengalami perubahan dari hasil penyampaian pada siklus II yang disampaikan pada proses konseling 
Jurnal HELPER, Vol 36 No 2 (2019) 08 - 16

Bimbingan dan Konseling Universitas PGRI Adi Buana Surabaya

ISSN: 02162938

individu, hal ini dapat dilihat dari hasil pengisian angket yang menghasilkan peningkatan pada persentase siklus II. Hasil skor pada siklus II lebih tinggi dari pada siklus I yaitu dari 58\% menjadi 89\%. Hal ini dapat membuktikan apabila layanan konseling individu dengan strategi pendekatan kognitif perilaku dapat meningkatkan penggunaan media sosial dengan bijak. Dapat dilihat pada diagram dibawah ini

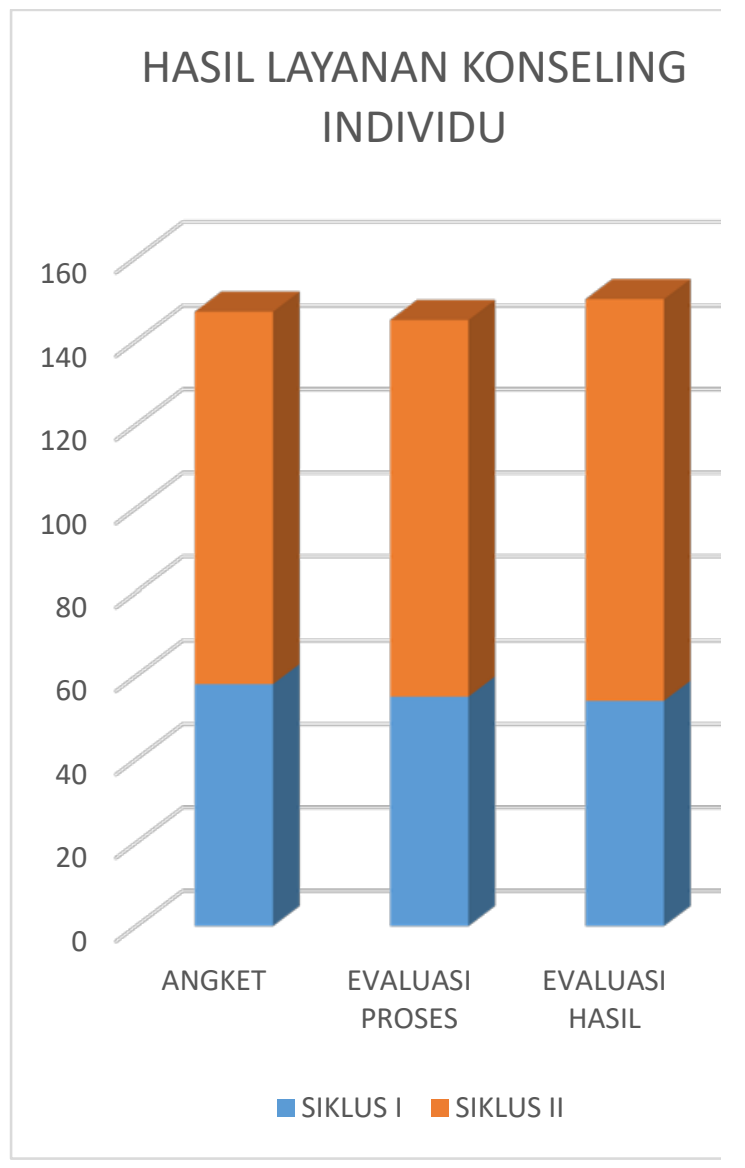

\section{SIMPULAN DAN SARAN}

a. Simpulan

Berdasarkan hasil penelitian yang telah dipaparkan selama dua siklus hasil seluruh pembahasan serta analisis yang telah dilakukan dapat disimpulkan bahwa layanan konseling individu dengan strategi pendekatan kognitif perilaku dapat meningkatkan penggunaan media sosial dengan bijak. Hal ini dibuktikan dengan persentase hasil dari angket siklus 1 (58\%) meningkat pada siklus II (89\%), evaluasi proses siklus I (55\%) meningkat pada siklus II (90\%) dan evaluasi hasil siklus I (54\%) meningkat pada siklus II (96\%).

a. Saran

Dari hasil penelitian yang diperoleh dari uraian sebelumnya agar proses layanan konseling individu dengan strategi pendekatan kognitif perilaku dapat di gunakan sebagai langkah preventif dalam meningkatkan penggunaan media sosial dengan bijak, maka disampaikan saran sebagai berikut:

1. Untuk melaksanakan layanan konseling individu dengan strategi pendekatan kognitif perilaku memerlukan persiapan yang cukup matang, sehingga guru BK/Konseli harus mampu menentukan dan memilah perangkat BK yang tepat dan sesuai dengan kebutuhan sehingga diperoleh dapat hasil yang optimal.

2. Dalam rangka meningkatkan penggunaan media sosial dengan bijak hendaknya terus membantu peserta didik/konseli dengan memantapkan pengetahuan yang 
Jurnal HELPER, Vol 36 No 2 (2019) 08 - 16

Bimbingan dan Konseling Universitas PGRI Adi Buana Surabaya

ISSN: 02162938

benar dan memantapkan konsep berpikir sehingga dapat mengubah perilaku negatif menjadi positif dengan melakukan self control sehingga peserta didik/konseli berhasil atau mampu memecahkan masalah-masalah yang dihadapinya terutama pengendalian perilaku yang tepat.

3 Perlu adanya penelitian yang lebih lanjut, karena hasil penelitian ini hanya dilakukan di Kelas X AB1 SMKN 1 Singosari semester gasal tahun pelajaran 2018/2019.

4. Untuk penelitian yang serupa hendaknya dilakukan perbaikanperbaikan agar diperoleh hasil yang lebih baik.

\section{DAFTAR PUSTAKA}

Abdul, Agus Rahman. 2013. Psikologi Sosial. Jakarta: Rajawali Pers.

Ambar. 2017. 20. Pengertian Media Sosial Menurut Para Ahli. https://pakarkomunikasi.com/pe ngertian-media-sosial-menurutpara-ahli

Raharja, Ivan Fauzani. 2019. Bijak Menggunakan Media Sosial di Kalangan Pelajar menurut Undang-Undang Nomor 19 Tahun 2016 Tentang Informasi dan Transaksi Elektronik. https://ojs.umrah.ac.id/index.ph p/selat/article/view/1437
Walgito, Bimo. (2010). Bimbingan dan Konseling. Yogyakarta: Yayasan Penerbit Fakultas Psikologi UGM.

Wilga Secsio Ratsja Putri, Nunung Nurwati, Meilanny Budiarti S. 2015. Pengaruh Media Sosial Terhadap Perilaku Remaja. http://jurnal.unpad.ac.id/prosidin g/article/view/13625 